\title{
Correction to: Maternal and neonatal outcomes in mothers with diabetes mellitus in Qatari population
}

Mohammad A. A. Bayoumi ${ }^{1 *}$, Razan M. Masri ${ }^{2}$, Nada Y. S. Matani ${ }^{2}$, Mohamed A. Hendaus $^{3}$, Manal M. Masri ${ }^{4}$, Prem Chandra ${ }^{5}$, Lisa J. Langtree ${ }^{6}$, Sunitha D'Souza ${ }^{1}$, Noimot O. Olayiwola $^{7}$, Saad Shahbal', Einas E. Elmalik', Mohamed S. Bakry ${ }^{8}$, Ashraf I. Gad ${ }^{1}$ and Ravi Agarwal ${ }^{1}$

\section{Correction to: BMC Pregnancy Childbirth 21, 651} (2021)

https://doi.org/10.1186/s12884-021-04124-6

Following publication of the original article [1], the authors reported an error in Tables 2 and 3. Below are the details.

In table 2: The percentage should be changed from 0.8 to $99.2 \%$ in the female row under the gender. This is really significant.

In table 3: The number and percentage $8 / 38(21.1 \%)$ should be opposite to yes not in the same line with no in the last row of major congenital anomalies. This is also significant.

The original article [1] has been updated.

\section{Author details}

${ }^{1}$ Neonatal Intensive Care Unit (NICU), Women's Wellness and Research Center (WWRC), Hamad Medical Corporation (HMC), P.O. Box 3050, Doha, Qatar. ${ }^{2}$ Department of Medical Education, Hamad Medical Corporation (HMC), Doha, Qatar. ${ }^{3}$ Pediatric Department, Sidra Medicine, Doha, Qatar. ${ }^{4}$ Al-Ahli Hospital, Doha, Qatar. ${ }^{5}$ Medical Research Center, Hamad Medical Corporation (HMC), Doha, Qatar. ${ }^{6}$ Medical Records Department, Women's Wellness and Research Center (WWRC), Hamad Medical Corporation (HMC), Doha, Qatar. ${ }^{7}$ Corporate Communications Department, Hamad Medical Corporation (HMC), Doha,
Qatar. ${ }^{8}$ Obstetrics and Gynecology Department, Faculty of Medicine, Fayoum University, Fayoum, Egypt.

Published online: 16 November 2021

\section{Reference}

1. Bayoumi MAA, Masri RM, Matani NYS, et al. Maternal and neonatal outcomes in mothers with diabetes mellitus in qatari population. BMC Pregnancy Childbirth. 2021;21:651 https://doi.org/10.1186/ s12884-021-04124-6.

The original article can be found online at https://doi.org/10.1186/s12884021-04124-6.

\footnotetext{
*Correspondence: moh.abdelwahab@hotmail.com

${ }^{1}$ Neonatal Intensive Care Unit (NICU), Women's Wellness and Research Center (WWRC), Hamad Medical Corporation (HMC), P.O. Box 3050, Doha, Qatar

Full list of author information is available at the end of the article
} original author(s) and the source, provide a link to the Creative Commons licence, and indicate if changes were made. The images or other third party material in this article are included in the article's Creative Commons licence, unless indicated otherwise in a credit line to the material. If material is not included in the article's Creative Commons licence and your intended use is not permitted by statutory regulation or exceeds the permitted use, you will need to obtain permission directly from the copyright holder. To view a copy of this licence, visit http://creativecommons.org/licenses/by/4.0/. The Creative Commons Public Domain Dedication waiver (http://creativecommons.org/publicdomain/zero/1.0/) applies to the data made available in this article, unless otherwise stated in a credit line to the data. 